\title{
Food Security Is None Of Your Business? Food Supply Chain Management In Support of A Sustainable Food System
}

\author{
Ari Paloviita \\ Department of Social Sciences and Philosophy, \\ University of Jyväskylä, Finland \\ Email: ari.paloviita@jyu.fi
}

\begin{abstract}
Food security is the principal outcome of any given food system and it can be defined in terms of a sustainable food system where the core goal is to feed everyone sustainably, equitably and healthily. A sustainable food system addresses needs for availability, affordability and accessibility, is diverse, ecologically-sound and resilient, and builds the capabilities and skills necessary for future generations. This paper identifies the essential elements of food supply chain management in support of a sustainable food system, which ultimately enhances food security. The existing food supply chain and food system literature is synthesized in order to study the correspondence between public interests towards sustainable food and corporate interests. Giant food retailers, food processors and manufacturers, and food service supply chains in particular, extend their global reach, influence food culture and may be more important in shaping food systems than governments. Thus, the paper proposes food security frameworks for both upstream and downstream supply chain management. It concludes that sustainable food system thinking and societal orientation towards food security can hold the key to unlocking the next wave of food supply chain innovation and growth, and offers implications and suggestions for future research.
\end{abstract}

Keywords: food security, sustainable food system, food supply chain management

\section{INTRODUCTION}

Undernourishment, hunger, malnutrition and overall food insecurity remains a central problem of the $21 \mathrm{st}$ century. Rapid expansion of the global population together with scarce water resources and declining biodiversity calls for sustainable food security (Krejci and Beamon, 2010) and a sustainable food system (Lang and Barling, 2012). Food security has also gained renewed interest in developed countries in general, due to climate change, the fluctuating prices of oil and food and the fear of global economic recession (Brunori and Guarino, 2010: 41-43). Moreover, with the public health emphasis on nutritional outcomes, food security has become a concept that applies to most consumers (Ericksen, 2008). Whereas agriculture and farming have been the traditional focus for many sustainable food system studies (Eakin, 2010: 78), they are not the main powers in the food system anymore. Lang and Heasman (2015: 9) state that the real driving force in changing the shape and dynamics of the food economy "is what happens off the farm in terms of processing, retail and food service". For example, Hattersley and Dixon (2010: 199) point out some of the major gaps in evidence relating to the role of supermarkets in shaping food culture, including social relations around food preparation and consumption, the impact of supermarket-driven supply chain transformations with respect to agricultural and related communities, and the interactions between environmental change and population health.

The focal company in the food supply chain is typically a manufacturing company (such as Nestlé, Unilever or Danone), retail company (such as Wal-Mart) or food service company (such as McDonald's). Although governments are still important in food governance, retailers, food service supply chains and food manufacturers are increasingly influential in how food policy choices are made and implemented. Companies consider food policymaking as part of their business strategies and are active and engaged in state policy arenas (Lang and Heasman, 2010, 21). For example, some food companies that used to concentrate on taste and quantity to drive consumption now focus on the fundamental need for better nutrition (Porter and Kramer, 2010). In addition, private sector governance of the food supply chain has generated new institutional forms such as product- and process-based standards and quality specifications between retailers, processors/manufacturers and producers (Barling, 2007). Multinational food companies have also aimed to tap markets for the poor in developing countries in a form of "Base of the Pyramid" projects, including new types of supply chain experiments (Gold and Heikkurinen, 2013). However, much of the potential markets related to sustainable food security, nutrition and health are currently overlooked both academically and business wise.

Today's food systems are inherently fast evolving, dynamic, full of economic, environmental and social risks and opportunities, with constant changes in consumer demands (Beske et al., 2014). The key point in management research is to develop new perspectives in order to address contemporary problems and challenges ("broader issues") beyond financial performance (Vaara and Durand, 2012) or "to marry the efficiency of business with the attainment of wider societal objectives" (Crane et al., 2014: 143-144). Food security can be seen as this wider societal objective. Yet today, the link between food security and food supply chain management is poorly understood. For example, in 
the editorial of the special issue of sustainable food supply chain management (International Journal of Production Economics), Li et al. (2014) associate food security with food safety issues, such as the horsemeat scandal in Europe. Although food security and food safety are related, food security as a concept refers to a broader set of sustainability issues.

The purpose of this study is to identify the crucial elements in food supply chains in support of a sustainable food system, which ultimately enhances food security. Hence, food security is defined here in terms of a sustainable food system, where the core goal is to feed everyone sustainably, equitably and healthily, which addresses needs for availability, affordability and accessibility, is diverse, ecologically sound and resilient, and which builds the capabilities and skills necessary for future generations (Sustainable Development Commission, $2009,10)$. In this paper, the correspondence between public interests toward a sustainable food system and private interests of corporate-led food supply chain management is the main focus. The paper proposes a food security framework for both upstream and downstream supply chain management and hence, represents an inquiry at the intersection of business needs and wider societal concerns, reflecting the complex interdependency between these two realities (see Gentile, 2002). In addition, this is an attempt towards the coalescence of two discourses: food security and sustainable food system (see Lang and Barling, 2012).

\section{FOOD SUPPLY CHAIN MANAGEMENT IN SUPPORT OF A SUSTAINABLE FOOD SYSTEM}

Achieving a sustainable food system is a complex problem that depends upon the success of multiple interacting components of food supply chain management and food policies. The dual system of food system governance, including largely corporate-led private governance and government-led public governance, is important in shaping food systems (Barling, 2007). Placing agency in context and acknowledging the interactions of a number of actors assuming various roles is also a crucial step (Vaara and Durand, 2012). Food systems serve different functions for different actors, who have different perceptions on the valuable outcomes of the food system (Ericksen et al., 2010: 30). From the public perspective, regulations designed by governments should develop clear and measurable social goals, set performance standards, define phase-in periods for meeting standards, and put in place universal performance reporting systems (Porter and Kramer, 2011; Crane et al., 2014).The essential elements of sustainable food systems, namely (1) feeding everyone sustainably, equitably and healthily, (2) availability, affordability and accessibility, (3) ecologically-sound and resilient and (4) maintaining capabilities and skills necessary for future generations (Sustainable Development Commission, 2009), are discussed in the next sections. Examples are provided to illustrate how these characteristics work to support sustainable food systems.

Currently, food supply chain management strategies focus on "supplier management for risks and performance" or "supply chain management for sustainable products" (Gold and Heikkurinen, 2013). However, a shift in focus from suppliers or products to sustainable food systems is needed in order to respond to emerging societal needs. Food supply chains can contribute to sustainable food security and sustainable food systems by addressing the essential elements of a sustainable food system.

\subsection{Feeding Everyone Sustainably, Equitably and Healthily}

The core goal of a sustainable food system is to feed everyone sustainably, equitably and healthily (Sustainable Development Commission, 2009). Instead of speaking simply about food security, we should now talk about sustainable food security, as food has a deep impact on the environment, health and society (Lang and Heasman, 2015: 9). Moreover, consumer confidence about the quality, origin and safety of food products is closely associated with the traceability of these products, especially during food scares resulting from unexpected events (Bourlakis et al., 2014).

Food supply chains can approach sustainable food security, nutrition and health from a strategic value perspective. Porter and Kramer (2011) propose a shared value perspective, which focuses, for example, on "improving growing techniques and strengthening the local cluster of supporting suppliers and other institutions in order to increase farmers' efficiency, yields, product quality and sustainability". In addition to improving upstream supply chain value, companies can apply a value perspective in the downstream supply chain by improving the nutrition and health of consumers. According to the Retail Forum for Sustainability (European Commission, 2015), "retailers are based in a strategic position at the intersection between producers upstream and consumers downstream to promote more sustainable consumption and production processes."

Food companies are also responsible for the safety of the food that they sell to their customers and consumers. This requires adequate food safety management along the whole food supply chain. The International Organization for Standardization (ISO) 22000 series, for example, integrates the principles of hazard analysis and the critical control point system (HACCP). The latter has become an internationally accepted food safety management system, with prerequisite programs such as good manufacturing practices (GMP) and good hygiene practices (GHP), to ensure that there are no weak links in the food supply chain (Kök, 2009). However, although the ISO 22000 standard has been internationally accepted and used, there is no legislative obligation within the EU, for example, to use it. The standard thus remains a voluntary management tool, with the initiative coming from the food industry (Kök, 2009).

\subsection{Availability, Affordability and Accessibility}

The second core goal of a sustainable food system is that culturally appropriate goals of availability, affordability and accessibility are pursued (Sustainable Development Commission, 2009). Availability, affordability and accessibility are the conventional dimensions of food 
102

security framework by the Food and Agriculture Organization (FAO) and addressing the needs for this goal is determined by the level of food production, stock levels, net trade, incomes, expenditure, markets and prices (Food and Agriculture Organization, 2008). Hence, in addition to an adequate supply of food at the national and international levels, household food security should be in focus as well. However, the 20th century model of food and agriculture raising output and lowering prices has put quantity before quality, causing environmental and health problems (Lang and Heasman, 2015, 9).

Although global sourcing continues to grow, some of the leading retailers have been keen to affirm their commitment to working with local and regional farms and small-scale processors (Jones et al., 2005; Oberholtzer et al., 2014). This could be at least partially in response to consumer demand and market potential (Dunne et al., 2011) and consequently, a local supplier network can be used as a buffer against disruptions in global supply chains. The implementation of local or civic farming structures, which reduce food miles and involve consumer participation in food supply chains, ultimately depends on population size, consumer behavior and climate conditions to produce adequate quantities of high-quality food year-round (Krejci and Beamon, 2010). In Finland, for example, fresh farming products are available only from June to November, whereas stored or greenhouse food products provide the only regional option between December and May. Majority of consumers, however, may prefer distant sources of food by utilizing seasonal products sourced globally. Sourcing food within global food supply chains offers considerable variety and attractive supply prices but it has also led to growing public concerns about working conditions, rates of remuneration, child labor and health and safety (Jones et al., 2005). In contrast, Dunne et al. (2001) believe that food retailers may act as a positive force due to the infrastructure they create for local food systems, although their entry into these systems may also create some tensions due to their differences with direct-market outlets. According to Bourlakis et al. (2014), sourcing inputs locally is an example of minimizing delivery and distribution costs. Moreover, reducing food miles has a positive effect on reducing fuel consumption and carbon emissions (Bourlakis et al. 2014), which can be appealing to consumers.

Responsible logistics management has emerged as a critical issue in food supply chain sustainability (Bourlakis et al., 2014). Logistics management can be divided into the following: control activities (transportation oversight, inventory management, production management and physical network administration); execution activities (warehousing and the actual transport of goods); and valueadded activities (manufacturing operations such as packaging and labeling) (Pullman and $\mathrm{Wu}, 2012$ : 193). Temperature-controlled supply chains, for example, are vital to the health and wellbeing of consumers (Smith and Sparks, 2004: 196) of fresh or frozen produce. In terms of supply chain vulnerability, a logistical system based on lean philosophy (i.e. stocking small stockpiles and restocking at the last possible moment) is vulnerable to disruptions caused by extreme weather conditions, IT system failures, interruptions to fuel and other energy supplies or delivery system problems (Niemi et al., 2013).
Operations and Supply Chain Management 10(2) pp. 35 - 46 (C) 2017

Food manufacturers, food retailers and food service companies have a central role both in supplier pricing and consumer pricing, as they aim to compete with food prices in order to maximize their consumer base. Generally, primary producers and manufacturers are put under commercial pressure to reduce prices by a highly concentrated retail sector, which is expanding aggressively (Bourlakis and Weightman, 2004: 9; Hughes, 2004: 106). This results in lower, sometimes even unfair, supplier prices, enhancing the development and consolidation of large, powerful farm corporations with mono-culture economies of scale (Pullman and $\mathrm{Wu}, 2012$ : 251; Lang and Heasman, 2015: 10). According to Bourlakis and Weightman (2004: 5), low returns to primary producers and simultaneously declining levels of farm subsidies pose a threat to domestic food supply in the manufacturing sector. Furthermore, in terms of consumer pricing, Lang and Heasman (2015: 224; 274; 243) note that current food prices do not necessarily reflect the full related environmental and health costs, and that food has actually become so inexpensive that it is almost devalued partly due to externalized social and environmental costs.

Allocation mechanisms, also known as the place variable in the 4Ps marketing mix of companies, govern where, when and how food can be accessed by consumers, and are widely determined by those food retailers that make marketing-related decisions (Ericksen, 2008). Due to hypermarketization, fewer food outlets are available in the modern food system and has resulted in residents in communities with limited availability of healthy foods being especially vulnerable to malnutrition, obesity and heart disease (Andreyeva et al., 2011). In the U.S., for example, low-income and minority populations are more likely to have limited supermarket access. In such areas, a fast food establishment, convenience store or non-chain grocery store may constitute the only source of food access for community residents (Andreyeva et al., 2011).

\subsection{Ecologically Sound and Resilient Food Systems and Supply Chains}

Another key element of a sustainable food system is that it is ecologically sound and resilient (Sustainable Development Commission, 2009). Healthy, nontoxic and regenerative environmental inputs and outputs are essential to maintaining long-term food production capacity (Krejci and Beamon, 2010). Environmental sustainability in the food system is associated especially to energy, water, soil, plants, animals, overall biodiversity, climate change, waste, urbanization, food miles, meat and dairy production and sustainable diets (Krejci and Beamon, 2010; Lang and Heasman 2015, 103-121). According to Lang and Heasman $(2015,4)$ the use and misuse of land, sea and other natural resources when producing food is one of the crucial sustainability challenges of the food system.

As sustainable food security becomes a central policy issue, vulnerability and resilience will be essential principles driving the reformulation of social research (Brunori and Guarino, 2010, 54). In terms of food system resilience, sustainable food system can also be defined as a productive system that is capable of responding to changing demands, which requires minimization of vulnerability (Fresco, 2009). There are exogenous natural drivers (such 
as climate change and other environmental volatility) and endogenous social drivers (such as food system governance) that increase vulnerability of the food system (Khazai et al., 2014). These vulnerability drivers have social and ecological outcomes, which may also be seen as vulnerability of intertwined social-ecological systems (Ericksen et al., 2010: 67-70).

In addition to the impacts of natural hazards and climate change, social causes such as market failures, poverty, political instability, institutional weakness and conflicts are now recognized as fundamentally linked to food insecurity (Devereux and Maxwell, 2001). Resilience is a concept that refers either to the amount of change that a food system can undergo and still retain function and structure, or the degree to which the food system is capable of self-organization and the ability to build capacity for learning and adaptation of the food system (Ericksen et al., 2010: 73)

Agriculture uses seventy percent of available fresh water worldwide (Pullman \& Wu, 2012: 251), which is a fact that has partially motivated Coca Cola to reduce its worldwide water consumption by $9 \%$ between 2004-2010 (Porter and Kramer, 2011). Food supply chains can contribute to a sustainable food system by limiting resource consumption and reducing their ecological footprints (Krejci and Beamon, 2010; Bourlakis et al., 2014). At the same time, sustainable energy and water use is directly linked to the production and operational costs of a company (Bourlakis et al., 2014). Process-based life cycle assessment (LCA) following the international standards ISO 14040 and ISO 14044 together with social life cycle assessment can be a useful tool to enable quantitative assessment of environmental and social impacts for a defined food system (Rothwell et al., 2016; Gold and Heikkurinen, 2013). In addition, according to Bourlakis et al. (2014), food waste is among the most pervasive sustainability issues in food supply chains since close to 50 percent of all food grown is lost or wasted in the food supply chain. Hence, reverse logistics, a concept applied to processes associated with recycling, reducing and reusing materials used in the production process (Bourlakis and Bourlakis, 2004: 226), will be an important item on the food security agenda in the future.

Although food systems are one of the main contributors to anthropogenic climate change (Neff et al., 2009), they are also simultaneously vulnerable to the impacts of climate change (Paloviita and Järvelä, 2015). Supply chain vulnerability assessments (Peck 2005) contribute to supply chain resilience (Ponis and Koronis, 2012) since they facilitate the proactive planning and design of food supply chain networks that anticipate unexpected and disruptive events. Diversity is generally considered important in creating resilience in the food system, as it allows the system to adapt to climate change, policy change and evolving resource issues (Pullman and Wu 2012: 256), and to preserve options in the event of a crisis (Ericksen, 2008).

\subsection{Capabilities and skills necessary for future generations}

It is important that food systems build capacities and skills to ensure that future generations can continue to produce food in a sustainable manner (Sustainable Development Commission, 2009). Sustainability-oriented capacities and skills are needed both in the production and consumption of food. For example, Burch and Lawrence (2010) criticize the current emergence of designer foods and wellness diets and call for a broader public health approach aiming to reduce the intake of junk food and increase exercise levels. Ultimately, capacity building for sustainable food systems should address sustainable culinary cultures encompassing both the contexts and transitions of practices related to all activities of a food system beyond everyday patterns of buying, cooking and eating food (Mäkelä and Niva, 2015; Niva et al., 2014).

According to Krejci and Beamon (2010), farmers should be educated in replacing agrochemicals with natural inputs, reducing irrigation, using conservation tilling practices and maintaining biodiversity. On the other hand, Porter and Kramer (2011) report on a redesigned procurement by Nestlé, which worked with its coffee growers, providing advice on farming practices, guaranteeing bank loans and helping secure plant stock, pesticides and fertilizers. Growers' income subsequently increased due to the greater yields and higher production quality, whereas Nestlé's reliable supply of coffee grew significantly (Porter and Kramer, 2011). Hence, while the food industry and retail sector could adopt an educational role in guiding sustainable farming, consumers could also be educated on how to develop sustainable and healthy diets. The food industry and retailers are deeply engaged with the media, and are highly skilled in using diverse media - from producing educational materials for schools to linking up with charities to increasing awareness of foodrelated issues (Lang and Heasman, 2015: 231). On the other hand, the targeting of children and obese consumers by advertisers can include food security risks, especially in the context of fast foods, soft drinks, confectionery and snacks. Although retailers increasingly promote themselves through signifiers of freshness, health and quality (Burch and Lawrence, 2005), they also devote significant resources to promoting highly processed fatty, salty and sugary foods with added chemicals (Winson, 2004; Ericksen, 2008). As a consequence, food supply chains have generated sizeable public health externalities with high economic and social costs, through the rise in diet-related non-communicable diseases, such as heart diseases, chronic type 2 diabetes and some cancers (Barling, 2007). According to Lockie and Williams (2010: 157), food retailers can have a substantial impact on health outcomes at a population level by influencing store layouts, the allocation of shelf space and the use of promotional materials on healthy and sustainable food. This more critical discussion about the role of supermarkets in public health is also proposed by Hattersley and Dixon (2010: 199). 


\section{FOOD SECURITY}

FRAMEWORK FOR UPSTREAM AND DOWNSTREAM SUPPLY CHAIN MANAGEMENT

Corporations and food supply chains can contribute to sustainable food systems and food security by developing their policies and practices for both upstream and downstream supply chain management. A two-level framework proposed here makes a distinction between upstream supply chain management and downstream supply chain management, because the former focuses on sustainable food production and the latter on sustainable food consumption. The main propositions for further testing are presented in the following section.

\subsection{Food Security Framework for Upstream Supply Chain Management}

At the upstream supply chain level, food security should be assessed in terms of sustainable primary production and processing, and the resilience of the upstream supply chain. Based on the existing literature, the following propositions for further testing can be made.

Limiting resource consumption and reducing ecological footprint are crucial environmental measures of upstream supply chain sustainability. Environmental concerns are relevant throughout the upstream food supply chain. This is not only in agriculture characterized by mass use of agrochemicals, but also in the excessive consumption of water, energy and other natural resources in the different phases of the upstream supply chain, and the carbon emissions derived through food supply chains, which seriously threaten the sustainable food system. In meat and dairy supply chains it is also important to consider how animals are reared, not to mention that domesticated animals have a high impact on land use, water and cereal use. Thus, rethinking food production, processing and manufacturing from a sustainable food system perspective is necessary in food supply chains. Noting the nuances of ecological and environmental thinking described above, Proposition 1 is offered.

Proposition 1: The process for defining food security framework for upstream supply chain management is moderated by ecological and environmental thinking.

Focal companies of global food supply chains need to address social sustainability issues related to working conditions, rates of remuneration, child labor and occupational health and safety. Inequities in the labor process, poor wages and poor working conditions in some sectors are continual problems in global food supply chains. Pools of cheap labor, often comprised of immigrants in Western countries, do the manual picking and grading tasks, which enables the cheap prices in supermarkets. Failure to address these issues leads to litigation risks, reputational risks and competitive risks. As such, Proposition 2 is offered.
Proposition 2: The process for defining food security framework for upstream supply chain management is moderated by social injustice and inequalities.

Supplier diversity is a key to upstream supply chain resilience. Upstream supply chain resilience can be improved by enriching supplier diversity. In particular, developing and building up the local supplier base decreases the vulnerability of retailers and manufacturers. A hybrid procurement strategy blends the flexibility of local suppliers and the advantages of scale of a broader domestic and international supplier network. Sustainable food supply chain cannot be solely based on global food supply chains with a blurring notion of seasonality and a tendency towards farming monoculture. As such, Proposition 3 is offered.

Proposition 3: The process for defining food security framework for upstream supply chain management is moderated by supplier diversity.

Supplier policies need to address the vulnerability of farms and SME's. Farms and SMEs are the key suppliers in the food system. However, contemporary food supply chains are characterized by unfair returns for key suppliers along the food supply chain, as the share of the consumer's food dollar that gets back to the farmer has dropped remarkably. Hence, farms and SMEs are increasingly vulnerable to policies of large retail and manufacturing companies, and addressing power relations in food supply chains is an even more important issue in times of centralization and hypermarketization. As such, Proposition 4 is offered:

Proposition 4: The process for defining food security framework for upstream supply chain management is moderated by vulnerability of farms and SME's.

\subsection{Food Security Framework for Downstream Supply Chain Management}

At the downstream supply chain level, food security should be assessed in terms of sustainable distribution and consumption, and resilience of the downstream supply chain. Based on the existing literature, the following propositions for further testing can be made.

Limiting food waste in distribution and consumption is a crucial measure of downstream supply chain sustainability. Food waste lies throughout the food supply chain, but particular focus should be on food consumption. Reducing waste through supermarket-led food supply chain management, such as zero waste policies, needs to be complemented with a focus on the flow of waste food from urban households. As such, Proposition 5 is offered.

Proposition 5: The process for defining food security framework for downstream supply chain management is moderated by food waste along the supply chain.

Focal companies of food supply chains need to address health and nutrition issues, including over-, underand mal-consumption. Food supply chain policies are already addressing sustainability, but an emerging 
sustainable food supply chain management discourse will have to champion nutrition, health and sustainability together, and approach, for example, sustainable protein supply chains and diets. Since western levels of food consumption and a shift to fatty and sugary diets have become very problematic from the sustainable food system perspective, food companies can apply choice-editing, which means that companies make changes in their product category before the products arrive on the supermarket shelf and before the consumer chooses the product that contributes to the total diet (Lang and Barling, 2012). As such, Proposition 6 is offered.

Proposition 6: The process for defining food security framework for downstream supply chain management is moderated by human health.

Diversity of distribution channels is a key to downstream supply chain resilience. Hypermarketization may increase inequality in terms of access to healthy food. Hence, the promotion of diverse distribution channels improves accessibility to food in different urban and rural regions. In addition, a more diverse distribution network decreases the food miles from food store to home. As such, Proposition 7 is offered.

Proposition 7: The process for defining food security framework for downstream supply chain management is moderated by food insecure areas.
Distribution and pricing policies need to address consumer resilience and sustainability. Consumers should be able to make informed choices and be able to eat what they like. However, consumers are very dependent on complex food supply chains, which makes them vulnerable to food supply chain policies. Hence, there should be more correspondence in distribution policies implemented by food retailers and sustainable dietary guidelines that meld environment, health and other societal criteria. Pricing policies implemented by food companies give signals to consumers to buy certain products. However, pricing policies can give misleading messages in terms of sustainable food systems, if hidden environmental, health and other social costs are externalized. Pursuit of low-cost food and belief in cheap food culture can cause food insecurity in the long run. Therefore, a full-cost accounting system could provide information on these external costs. As such, Proposition 8 is offered.

Proposition 8: The process for defining food security framework for downstream supply chain management is moderated by cost internalisation.

Food security framework for upstream and downstream food supply chain management is illustrated in Figure 1. Key moderators informing the design of future interventions in food supply chain management are listed in the bottom of the figure.

\section{FOOD SYSTEM}

Food security is a principal outcome of any given food system and it can be defined in terms of sustainable food system where the core gaal is to feed everyone sustoinably, equitably and healthily. $A$ sustainable food system addresses needs for availability, affordability and accessibility, is diverse, ecologically-sonndand resilient, and builds the coppobilities and stills for futwe generations. (Sustainable Development Commission, 2009)

\section{Upstream food supply chain Focal company Downstream food supply chain}

\section{Suppliess Processhng'manufacturing company, Retaller, Foad service company Consumers}

1. Ecological and environmental thinking

2. Social injustice and inequalities

3. Supplier diversity

4. Vainerability of farms and SME's
5. Food waste along the supply chain

6. Homman health

7. Food insecure areas

8. Cost intermalisation

Figure 1 Food supply chain management in support of a sustainable food system 


\section{CONCLUSIONS AND FUTURE WORK}

Much of previous work related to sustainable food supply chain management focus on agriculture and farming and their environmental sustainability. Hence, the main response towards sustainability challenges by focal food companies has been supplier management for risks and performance. In a modern food system, however, the role of food manufacturers, food retailers and food service companies themselves is crucial in shaping the food system. Supply chain management for sustainable products is an important step towards sustainable product systems, but a focus on developing a more comprehensive food system is needed. Redesigning the food system for sustainability and resilience means that food supply chain management should be defined by multiple social, environmental and economic criteria. However, corporations have skills, resources and management capabilities to lead social progress towards sustainable food security in ways that public sector can rarely match (Porter and Kramer, 2011). In addition, policymakers find it hard to address the inter-relatedness of the whole food supply chain and are more used to addressing single issue problems (Lang and Barling, 2012). Governments' interests in collaborating with food businesses will inevitably grow when companies emphasize creating societal value and realize the value of connecting companies' successes with improvements in sustainable food security, nutrition and health.

Potential avenues for future research are related to specific case studies focusing on more specific upstream and downstream supply chain policies and practices. Identifying the societal needs and vulnerabilities embodied in the food supply chains, both upstream and downstream, could be the starting point, and it has become necessary for short- and long-term reorientation of food supply chains to align environmental, health and inter- and intra-societal inequalities (Lang and Barling 2012), which emphasize the role of large food manufacturers, retailers and food service companies. This ongoing exploration of societal needs and vulnerabilities will eventually lead to exploring opportunities and innovations at the food supply chain level. It is also important that food corporations pursue tough ethical, social and environmental standards beyond the state legislation. Traditional supply chain concepts need to be broken up and new types of supply chain experiments, such as choice-editing and full-cost accounting, need to be promoted.

\section{ACKNOWLEDGEMENTS}

I would like to thank the Kone Foundation for financing our research project: "Future Food Security in Finland - Identifying and Analyzing Vulnerability Aspects in the Finnish Food System". Additionally, I would like to thank the Foundation for Economic Education (Finland), which enabled my attendance at the 7th International Conference on Operations and Supply Chain Management, which took place in Thailand in December, 2016. I would also like to thank the anonymous referees for their helpful comments and suggested improvements.

\section{REFERENCES}

Andreyeva, T., Middleton, A.E., Long, M.W., Luedicke, J. \& Schwartz, M.B. (2011). Food retailer practices, attitudes and beliefs about the supply of healthy foods. Public Health Nutrition 14(6), pp. 1024-1031. doi: $10.1017 / \mathrm{S} 1368980011000061$.

Barling, D. (2007). Food supply chain governance and public health externalities: upstream policy interventions and the UK state. Journal of Agricultural and Environmental Ethics 20, pp. 285-300. DOI 10.1007/s10806-007-9034-0.

Beske, P., Land, A. \& Seuring S. (2014). Sustainable supply chain management practices and dynamic capabilities in the food industry: A critical analysis of the literature. International Journal of Production Economics 152, pp. 131-143. http://dx.doi.org/10.1016/j.ijpe.2013.12.026

Bourlakis, C. \& Bourlakis, M. (2004), The future of food supply chain management. In: M.A. Bourlakis \& P.W.H. Weightman (Eds.) Food Supply Chain Management, Blackwell, Oxford, pp.221-230.

Bourlakis, M. \& Weightman, P. (2004), Introduction to the UK food supply chain. In: M.A. Bourlakis \& P.W.H. Weightman (Eds.) Food Supply Chain Management, Blackwell, Oxford, pp.1-10.

Bourlakis, M., Maglaras, G., Aktas, E., Gallear, D. \& Fotopoulos, C. (2014). Firm size and sustainable performance in food supply chains: Insights from Greek SMEs. International Journal of Production Economics 152, pp. 112-130. http://dx.doi.org/10.1016/j.ijpe.2013.12.029.

Brunori, G. \& Guarino, A. (2010), Security to whom? Changing discourses on food in Europe in times of a global food crisis. In G. Lawrence, K. Lyons \& T. Wallington (eds) Food security, nutrition and sustainability, Earthscan, Oxon, pp.41-60.

Burch, D. \& Lawrence, G. (2005). Supermarket own brands, supply chains and the transformation of the agri-food system. International Journal of Sociology of Agriculture and Food 13(1), pp. 1-18.

Burch, D. \& Lawrence, G. (2010), The "wellness" phenomenon: Implications for global agri-food systems. In G. Lawrence, K. Lyons \& T. Wallington (eds) Food security, nutrition and sustainability, Earthscan, Oxon, pp.175-187.

Crane, A., Palazzo, G., Spence, L.J. \& Matten, D. (2014). Contesting the value of "Creating shared value". California Management Review 56(2), pp. 130-154.

Devereux, S. \& Maxwell, S. (2001), Food Security in SubSaharan Africa, ITDG Publishing, London.

Dunne, J.B., Chambers, K.J., Giombolini, K.J. \& Schlegel, S.A. (2010). What does "local" mean in the grocery store? Multiplicity in food retailers' perspectives on sourcing and marketing local foods. Renewable Agriculture and Food Systems 26(1), pp. 46-59. doi: 10.1017/S1742170510000402.

Dyllick, T. \& Hockerts, K. (2002). Beyond the business case for corporate sustainability. Business Strategy and the Environment 11(2), pp. 130-141. DOI: 10.1002/bse.347.

Eakin, H. (2010), What is vulnerable, in: Ingram, J., Ericksen, P., and Liverman, D. (eds.) Food Security and Global Environmental Change, Earthscan, Oxon, pp. 78-86.

Ericksen, P. (2008). Conceptualizing food systems for global environmental change research. Global Environmental Change 18, pp. 234-245. doi:10.1016/j.gloenvcha.2007.09.002

Ericksen, P., Stewart, P., Dixon, J., Barling, D., Loring, P., Anderson, M. \& Ingram J. (2010). The value of food system approach. In: J. Ingram, P. Ericksen \& D. Liverman (eds) Food security and global environmental change, pp. 25-45. Oxon: Earthscan. 
Paloviita: Food Security Is None Of Your Business? Food Supply Chain Management In Support Of A Sustainable Food System Operations and Supply Chain Management 10(2) pp. 35 - 46 (C) 2017

European Commission. (2015). Retail forum: about the retail forum.

http://ec.europa.eu/environment/industry/retail/about.htm. Accessed 1 December 2015.

Food and Agricultural Organization (FAO). (2008). An introduction to basic concepts of food security. Available at: http://www.fao.org/docrep/013/a1936e/al936e00.pdf, accessed 13 November, 2015.

Fresco, L.O. (2009). Challenges for food system adaptation today and tomorrow. Environmental Science \& Policy 12, pp. 378385.

Gentile, M.C. (2002). Social impact management: a definition. The Aspen Institute, New York. https://www.aspeninstitute.org/sites/default/files/content/doc s/bsp/SOCIALIMPACTMANAGEMENT.PDF. Accessed 1 December 2015.

Gold, S. and Heikkurinen, P. (2013). Corporate responsibility, supply chain management and strategy: In search of new perspectives for sustainable food production. Journal of Global Responsibility 4(2), pp. 276-291.

Hattersley, L. \& Dixon, J. (2010). Supermarkets, food systems and public health: Facing the challenges. In G. Lawrence, K. Lyons \& T. Wallington (eds). Food security, nutrition and sustainability, Earthscan, Oxon, pp.188-203.

Hughes, D. (2004), Food manufacturing. In: M.A. Bourlakis \& P.W.H. Weightman (Eds.) Food Supply Chain Management, Blackwell, Oxford, pp.99-105.

Jones, P., Comfort, D., Hillier, D. \& Eastwood, I. (2005). Corporate social responsibility: a case study of the UK's leading food retailers. British Food Journal 107(6), pp. 423435. DOI 10.1108/00070700510602192.

Khazai, B., Kunz-Plapp, T., Büscher, C. and Wegner, A. (2014). VuWiki: An ontology-based semantic Wiki for Vulnerability assessments. International Journal of Disaster Risk Science 5, pp. 55-73.

Krejci, C.C. and Beamon, B.M. (2010). Environmentallyconscious supply chain design in support of food security. Operations and Supply Chain Management 3 (1), pp. 14-29.

Kök, M.S. (2009). Application of food safety management systems (ISO 22000/HACCP) in the Turkish poultry industry: A comparison based on enterprise size. Journal of Food Protection 72(10), pp. 2221-2225.

Lang, T. (2010). From "value-for-money" to "values-for money"? Ethical food and policy in Europe. Environment and Planning A 42(8), pp. 1814-1832. DOI: 10.1068/a4258.

Lang, T. \& Barling, D. (2012). Food security and food sustainability: reformulating the debate. The Geographical Journal 178(4), 313-326.

Lang, T. \& Heasman, M. (2015), Food wars: the global battle for mouths, minds and markets, Second edition, Earthscan, Oxon.

Li, D., Wang, X., Chan, H.K. and Manzini, R. (2014). Editorial: Sustainable food supply chain management. International Journal of Production economics 152, pp. 1-8.

Lockie, S. \& Williams, S. (2010). Public health and moral panic: Sociological perspectives on the "epidemic of obesity". In G. Lawrence, K. Lyons \& T. Wallington (eds). Food security, nutrition and sustainability, Earthscan, Oxon, pp.145-161.

Mäkelä, J. \& Niva, M. (2015), Citizens and sustainable culinary cultures. In A. Paloviita \& M. Järvelä (Eds.) Climate change adaptation and food supply chain management, Routledge, Oxon, pp.172-182.
Neff, R.A., Chan, I.L. \& Clegg Smith, K. (2008). Yesterday's dinner, tomorrow's weather, today's news? US newspaper coverage of food system contributions to climate change. Public Health Nutrition 12(7), pp. 1006-1014. doi: $10.1017 / \mathrm{S} 1368980008003480$.

$\begin{array}{cccc}\text { Nestle. (2016). About us: } & \text { Strategy. } \\ \text { http://www.nestle.com/aboutus/strategy. } & \text { Accessed } 5\end{array}$ January, 2016.

Niemi, J., Knuuttila, M., Liesivaara, P. \& Vatanen, E. (2013). Finland's food security and maintenance and supply security: The current situation and future prospects. Agrifood Research Centre Finland, Jokioinen. http://www.mtt.fi/mttraportti/pdf/mttraportti80.pdf. Accessed 1 December 2015.

Niva, M., Mäkelä, J., Kahma, N. \& Kjaernes, U. (2014). Eating sustainably? Practices and background factors of ecological food consumption in four Nordic countries. The Journal of Consumer Policy 37, pp. 465-484. DOI 10.1007/s10603014-9270-4.

Oberholtzer, L., Carolyn, D. \& Jaenicke, E.C. (2014). Examining U.S. food retailers' decisions to procure local and organic produce from farmer direct-to-retail supply chains. Journal of Food Products Marketing 20(4), pp. 345-361. DOI: 10.1080/10454446.2013.807401.

Paloviita, A. \& Järvelä, M. (Eds.) (2015), Climate Change Adaptation and Food Supply Chain Management, Routledge, Oxon.

Ponis, S.T. and Koronis, E. (2012). Supply chain resilience: definition of concept and its formative elements. Journal of Applied Business Research 28(5), pp. 921-929.

Porter, M.E. \& Kramer, M.R. (2011). Creating shared value. Harvard Business Review 89(1-2), pp. 62-77.

Pullman, M. \& Wu, Z. (2012), Food supply chain management: Economic, social and environmental perspectives, Routledge, New York.

Rothwell, A., Ridoutt, B., Page, G. and Bellotti, W. (2016). Environmental performance of local food: trade-offs and implications for climate resilience in a developed city. Journal of Cleaner Production 114(5), pp. 420-430.

Smith, D. \& Sparks, L. (2004), Temperature controlled supply chains. In: M.A. Bourlakis \& P.W.H. Weightman (Eds.) Food Supply Chain Management, Blackwell, Oxford, pp.179-198.

Sustainable Development Commission. (2009). Food security and sustainability: the perfect fit. SDC position paper. http://www.sd-commission.org.uk/data/files/publications/ SDCFoodSecurityPositionPaper.pdf. Accessed 12 December 2016.

Tjärnemo, H. \& Södahl, L. (2015). Swedish food retailers promoting climate smarter food choices - Trapped between visions and reality? Journal of Retailing and Consumer Services 24, pp. 130-139.

UNEP. (2009). The environmental food crisis. http://www.unep.org/pdf/FoodCrisis_lores.pdf. Accessed 26 November 2014.

Unilever. (2016). About Unilever. https://www.unilever.com/about/who-we-are/aboutUnilever/. Accessed 5 January 2016.

Vaara, E, \& Durand, R. (2012). How to connect strategy research with broader issues that matter? Strategic Organization 10, pp. 248-255. DOI: 10.1177/1476127012452827

Winson, A. (2004). Bringing political economy into the debate on the obesity epidemic. Agriculture and Human Values 21, pp. 299-312

Ari Paloviita, DSc Econ., is a senior researcher in the Food System Studies Research Group in the Department of Social Sciences and Philosophy at the University of Jyväskylä, Finland. He is Adjunct Professor in Environmental Management 
Paloviita: Food Security Is None Of Your Business? Food Supply Chain Management In Support Of A Sustainable Food System $\underline{108}$ Operations and Supply Chain Management 10(2) pp. 35 - 46 (C) 2017

(University of Eastern Finland) and specialises in food supply chain management and sustainable food systems. He recently published an edited book titled Climate Change Adaptation and Food Supply Chain Management (Routledge, 2015). He is currently involved in two research projects: Future Food Security in Finland - Identifying and Analyzing Vulnerability Aspects in the Finnish Food System (funded by Kone Foundation) and Novel Protein Sources for Food Security (funded by the Strategic Research Council at the Academy of Finland). 